\title{
Pharmacological, phytochemical, and traditional uses of Plumeria alba LINN. an Indian medicinal plant
}

\author{
Jagdish Sura, Sumeet Dwivedi, Raghvendra Dubey \\ Department of Pharmacy, College of Pharmacy, Dr. APJ Abdul Kalam University, Indore, Madhya Pradesh, India
}

Correspondence:

Sumeet Dwivedi,

College of Pharmacy,

Dr. APJ Abdul Kalam University, Indore,

Madhya Pradesh, India.

Phone: +91-9893478497,

E-mail: herbal0914@rediffmail.com

\begin{abstract}
Plumeria alba is small laticiferous tree or shrub is a native of tropical America, commonly known as White Champa Leaf and stem were evaluated for its phytoconstituents, which is used in several traditional medicines to cure various diseases. The plant is mainly grown for its ornamental and fragrant flowers, are also known for their medicinal importance. Leaves arrangement is lanceolate to oblanceolate with white flowers, fragrant in corymbose fascicles, and fruit is edible. Their medicinal properties are often due to their latex which is frequently drastic and corrosive. Latex is applied to ulcers, herpes, and scabies. Seeds possess hemostatic properties. Moreover, its bark is bruised and applied as plaster over hard tumors. Whereas the others finds use as purgative, cardiotonic, diuretic, and hypotensive. The medicinal value of this Plumeria species in the treatment of a large number of human ailments is mentioned in Ayurveda, Charaka Samhita, and Sushrita Samhita. For millennia, the Indian population has depended mainly on plant-based crude drugs for a variety of ailments. This alternative system of medicine is gaining increasing popularity worldwide.
\end{abstract}

Keywords: Plumeria alba, phytochemistry, pharmacological activity, uses

\section{Introduction}

Plumeria common name Plumeria or frangipani in a genus of flowering plants in the dogbane family, Apocynaceae. It contains primarily deciduous shrubs and small trees. ${ }^{[1]}$ The flowers are native to Central America, Mexico, the Caribbean, and South America as far south as Brazil but can be grown in tropical and sub-tropical regions. ${ }^{[2]}$ Plumeria alba is a small laticiferous tree or shrub, a native of tropical America. It is $4.5 \mathrm{~m}$ high, occasionally grown in the gardens. The plant is mainly grown for its ornamental and fragrant flowers. Leaves lanceolate to oblanceolate, flowers white, fragrant in corymbose fascicles. ${ }^{[3]}$ The fruit is edible; latex is applied to ulcers, herpes and scabies and seeds possess hemostatic properties. Moreover, its bark is bruised and applied as plaster over hard tumors. ${ }^{[4]}$ Whereas the latter taxon finds use as purgative, cardiotonic, diuretic, and hypotensive. ${ }^{[5]}$ Methanolic extract showed antimicrobial activity

\section{Access this article online}

Website: http://www.jpbs-online.com

E-ISSN: $2321-0125$

DOI: $10.31555 / j p b s / 2018 / 6 / 1 / 1-4$

How to cite this article: Sura J, Dwivedi S, Dubey R. Pharmacological, phytochemical, and traditional uses of Plumeria alba LINN. an Indian medicinal plant. J Pharm BioSci $2018 ; 6(1): 1-4$

Source of Support: Nil, Conflict of Interest: None declared. against Bacillus anthracis, Pseudomonas aeruginosa. ${ }^{[6]}$ The plant is reported to contain amyrinacetate, mixture of amyrins, $\beta$-sitosterol, scopotetin, the iriddoids isoplumericin, plumieride, plumieride coumerate, and plumieride coumerate glucoside. ${ }^{[7,8]}$

\section{$P$. alba (White Frangipani)}

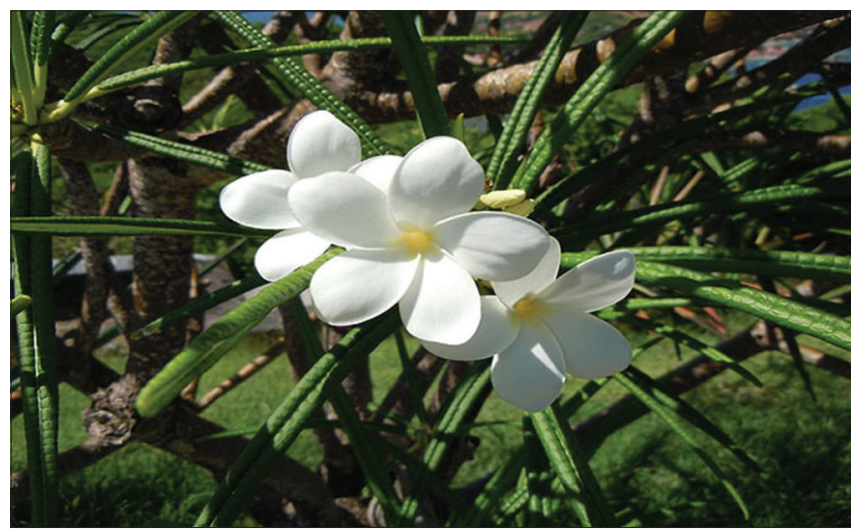

\section{Geography}

Frangipani is a native to the tropcal areas but does well in any frostfree areas. The branches and stems are thick and fleshy. The tree has a typical V shape. The bark is tender and when cut white sap appears which can be irritant. The flowers are large funnel-shaped, white and yellow in the middle with an amazing fragrance. When flowers drop can make litter around. The plant can tolerate drought and some salt. 
Frangipani is well-known for its intensely fragrant. Lovely, spiralshaped blooms which appear at branch tips June through November. The tree itself is rather unusual in appearance; the 20-inch-long, coarse, deciduous leaves clustered only at the tips of the rough, blunt, sausage-like, thick, grey-green branches. Branches are upright and rather crowded on the trunk forming a vase or umbrella shape with age. They are rather soft and brittle and can break but are usually.

Sturdy unless they are mechanically hit or disturbed. A milky sap is exuded from the branches when they are bruised or punctured.

\section{Growing Season and Type}

1. Plant the white Plumeria in a fertile, well-draining spot in full summer sun. This tree prefers a $\mathrm{pH}$ between 6.1 and 7.5 and will tolerate loam, sand or clay soils, although a fertile site is the best.

2. Water the young white Plumeria periodically in the absence of rain. One inch of water weekly throughout the growing season is sufficient. Do not overwater to avoid rotting this plant's roots.

3. Feed white Plumeria twice monthly throughout the growing season. Use a good water-soluble, high-phosphorus fertilizer.

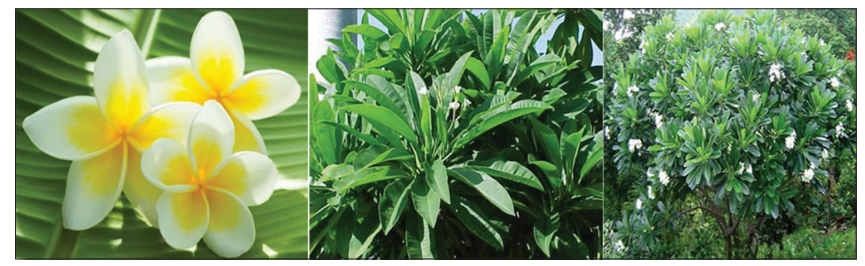

1. Flower of P. alba

2. Leaf of P. alba

3. P. alba tree

\section{General information}

- Scientific name: P. alba.

- Common name(s): White Frangipani/caterpillar tree/pagoda tree/pigeon wood/nosegay tree/white frangipani.

- Family: Apocynaceae.

- Availability: Generally, available in many areas within its hardiness range.

- Native Range: Puerto Rico, Lesser Antilles

- Zone: 10 to 12

- Height: 15.00 to 25.00 feet

- Spread: 15.00 to 25.00 feet

\section{Leaves}

Simple, alternate, oblong to elliptic, thick and leathery, many to 14 inches long and $1 \frac{1}{2}$ inches wide, strongly recurved margins, hairless on upper surface, whitish below, many lateral veins almost at right angle from the midribs.

\section{Flowers}

Salverform, five waxy white petals, with yellow centers, arranged on cymes on branch tips.

\section{Fruits}

Not shown. Follicles, brown long-pointed, usually borne in pairs.

\section{Morphological Characteristics}

White Frangipani can grow as either a small shrub or tree ranging in height from 0.9-6.1 m with widely spaced thick succulent branches that are often covered with "knobby" protuberances. The leaves are clustered near the tips of the branches. They are large, 6-22 cm long, 2-7 $\mathrm{cm}$ wide, and have a characteristic obovate shape and the tip of the leaf is rounded, rather than pointed as it is in other species. The leaves are dark and leathery and tend to be shiny on the upper surface with conspicuous parallel secondary veins that run from the midvein to the margins of the leaves. The flowers of this species are borne in clusters that form at the ends of the branches on a long thick stalk. Each inflorescence contains many white flowers with a small yellow center. Flowers contain five petals that are fused at the base in a short funnel-shaped tube which gradually widens as the lobes of the petals are spread out. The fruit of this species is a dry follicle which splits along one side to release the winged seeds.

\section{Microscopy}

The powder of bark was found to be brown in color with slightly bitter taste and odorless. On microscopically examination, the powder showed sclerenchyma, parenchyma cells, phloem fibers, starch grains, and cork cells. Different parameters, i.e., Total ash, acid insoluble ash, water soluble ash, loss on drying, and swelling index were found to be $6.0,2.3,1.8,1.33$, and 20.0, respectively. ${ }^{[9]}$ The hot water soluble extractive was high in the bark of $P$. alba. Preliminary phytochemical screening reveals the presence of alkaloids, carbohydrates, flavonoids, phenolic compounds, and tannins in this plant. ${ }^{[8]}$

\section{Phytochemical Constituents}

The bark of $P$. alba containing alkaloids, carbohydrates, flavonoids, phenolic compounds, and tannins. ${ }^{[10]}$ The plant is reported as medicinally important being having amyrin acetate, mixture of amyrins, B-sitosterol, scopotetin, the iriddoidsiso plumericin, plumieride, plumieride, coumerate, and plumieride coumerate glucoside. ${ }^{[11]}$ The flower oil mainly consists of primary alcohol, such as geraniol, citronellol, farnesol and phenyl ethyl alcohol, and some linalool. The flowers contain quercetin and kaempferol. ${ }^{[12]}$

\section{Pharmacology activity}

\section{Antimicrobial activity}

P. alba appears to have significant antimicrobial capacity resembling a broad spectrum antibiotic against the common uro-gastro pathogenic Escherichia coli, one of the common bacteria with pathogenic strains and are relatively resistant towards synthetic drugs. This aromatic plant can be a potential source of evolving newer antimicrobial compound and as a non-toxic antibiotic producer agent. The extracts of frangipani have a potential as a natural anti-toxic antibiotic producer, especially against E. coli. ${ }^{[13]}$ 
Antibacterial activity of $P$. alba (Frangipani) petals methanolic extracts were evaluated against E. coli, Proteus vulgaris, Staphylococcus aureus, Klebsiella pneumoniae, P. aeruginosa, Staphylococcus saprophyticus, Enterococcus faecalis, and Serratia marcescens using disk diffusion method. Frangipani extract also showed high antibacterial activity against S. saprophyticus, $P$. vulgaris, and S. marcescens, but not more than the zones of the positive control used..$^{14,15]}$

\section{Larvicidal activity}

Leaves extract of P. alba found (LC50 218.8 ppm) against Aedes aegypti mosquitoes. ${ }^{[1,16]}$

\section{Hepatoprotective Activity}

Hepatoprotective activity of $P$. alba extract against paracetamol induced hepatotoxicity in rats. The methanol extract at different doses (100, 200, and $400 \mathrm{mg} / \mathrm{kg}$ ) of the plant P. alba Lam. syn. Plumeria acutifolia. Poir were tested for its efficacy against paracetamol-induced acute hepatic damage in Wistar rats. Methanolic extract of $P$. alba did not produce any toxic symptoms or mortality up to the dose level of $2000 \mathrm{mg} / \mathrm{kg}$ body weight in mice, and hence the extract was considered to be safe and non-toxic for further pharmacological screening. The normal control group showed a normal liver architecture, hepatocytes very well arranged, central vein without alterations. ${ }^{[17]}$

\section{Antiarthritic activity}

The anti-arthritic potential of ethyl acetate and n-butanol fractions (100 and $200 \mathrm{mg} / \mathrm{kg}$, p.o.), respectively of hydroalcoholic extract from leaves of $P$. alba were evaluated in vivo models of rodents by using formaldehyde-induced acute non-immunological and Freund's Complete Adjuvant-induced chronic immunological arthritis in Sprague-Dawley rats. Antiarthritic potential of fractions may be due to the protection of synovial membrane, vascular permeability, prevention of cartilage destruction.

\section{Anti-fungal activity}

Antifungal activities of methanolic extract and the isolated fraction of the plant P. alba was assessed by standard dilution test using MuellerHinton agar (MH) medium. The zone of inhibition was compared with that of Standard antibiotic ciprofloxacin ( $5 \mathrm{mg} /$ disc) by disc diffusion method. The anti-fungal activity was assessed by standard dilution technique using Sabouraud dextrose agar medium. The results are compared with standard Clotrimazole $(125 \mathrm{mcg} / \mathrm{ml}) .{ }^{[14,18]}$

\section{Phyto-constitutes}

P. alba possesses various bioactive constituents such as sterols, carbohydrates, tannins, triterpenoids, and iridoid glycosides. The aerial part of the plant, i.e., leaves stems, etc., are reported to contain steroids, flavonoids, and alkaloids 35 . The plant is reported to contain mixture of amyrins, $\beta$ sitosterols copotein, iriddoids isoplumericin, plumeride, plumeride coumerate, and plumeride coumerate glucoside 36,37 . The fresh leaves and bark contain pluieride, resinic acid, and fulvoplumierin, a mixture of terpenoids, sterols, and plumieride. Bark of the plant contains cytotoxic iridoids, fulvoplumierin, Allamcin,Allamandin, 2,5-dimethoxyp-benzoquinone, plumericin, and lignin liriodinndrin. The root bark of P. alba shows the presence of iridiods, tannins, and alkaloids 38 .

P. alba bark containing alkaloids, carbohydrates, flavonoids, phenolic compounds, and tannins. ${ }^{[12]}$ The plant is reported as medicinal which contains amyrin acetate, mixture of amyrins, $\beta$-sitosterol, scopotetin, the iriddoids isoplumericin, plumieride, plumieride coumerate, and plumieride coumerate glucoside. ${ }^{[19]}$ The flower oil mainly consists of primary alcohol, viz.

Geraniol, citronellol, farnesol and phenyl ethyl alcohol and some linalool. The flowers contain quercetin and kaempferol. ${ }^{[1]}$

\section{Uses}

Different part of the P. alba was believed, have been useful in a variety of diseases, namely, the diseases of Malaria, Leprosy, Rheumatism, and abdominal tumors. The milky sap of the stem and leaf is applied to skin diseases such as herpes, scabies, and ulcers. ${ }^{[20,21]}$ Its bark is used as plaster over hard tumors, the seeds in hemostasis while the latex is used as purgative, cardiotonic, diuretic, and hypotensive. ${ }^{[8]}$

P. alba is also used in the treatment of ulcers, herpes, scabies, and seeds possess hemostatic properties. The bark is bruised as plaster over hard tumors. ${ }^{[1]}$

\section{Conclusion}

The all P. alba Linn. Scientifically use for the Medicinal activity.

\section{References}

1. Goyal RK, Goyal G, Goyal S, Mittal S. Pharmacognostical evaluation of bark of Plumeria alba Linn. Int J Nat Prod Sci 2012;1:178.

2. Henry AN, Kumeri GR, Chitra V. Flora of Tamil Nadu, India. Coimbatore: BSI; 1987. p. 78.

3. Chopra RN, Nayar SL, Chopra IL. Glossary of Medicinal Plants. New Delhi: CSIR; 1956. p. 1984.

4. Hartwell JL. Plants Used Against Cancer: A Survey. Lawrence, MA: Quarterman Publications, Inc.; 1982. p. 408.

5. Kirtikar KR, Basu BD. Indian Medicinal Plants. Part II. $3^{\text {rd }}$ ed. Dehradun: International Book Distributors; 1935. p. 1548.

6. Asolkar LV, Kakkar KK, Chakre OJ. Second Supplement to Glossary of Indian Medicinal Plants with Active Principles. New Delhi: CSIR; 1992. p. 173.

7. Nargis A, Malik A, Saminanoor A. A new anti bacterial triterpenoid from Plumeria alba. Fitoterapia 1993;2:162-6.

8. Rengaswami S, Venkatarao E. Chemical components of Plumeria alba. Proc Indian Acad Sci 1960;52:173-81.

9. Goyal RK, Goyal K, Goyal S, Mittal S. Pharmacognostical evaluation of bark of Plumeria alba Linn. Int J Nat Prod Sci 2012;1:178.

10. Gilman EF, Watson DG. Plumeria alba, White Frangipani. 1994

11. Anonymous. The Wealth of India-Raw Materials. New Delhi: Council of Scientific and Industrial Research; 2005. p. 164-6.

12. Siddiqui BS, Naeed A, Begum S, Iddiqui S. Minor iridoids from the leaves of Plumeria obtusa. Phytochemistry 1994;37:769-71. 
13. Zahid Z, Khan SW, Patel KA, Konale AG, Lokre S. Antimicrobial activity of essential oil of flowers of Plumeria alba Linn. J Pharm Phytochem Sci 2010;2:155-7.

14. Radha R, Sriram L, Narayanan N. Antibacterial and antifungal activities of methanolic extract and the isolated fraction of Plumeria alba Linn. Nat Prod Radiance 2008;4:13-16.

15. Syakira MH, Brenda L. Antibacterial capacity of Plumeria alba petals. World Acad Sci Eng Technol 2010;44:1473-6.

16. Kaushik R, Saini P. Screening of some semi-arid region plants for larvicidal activity against Aedes aegypti mosquitoes. J Vector Born Dis 2009;46:244-6.

17. Chowdhur A, Dasgupta B, Ganesh E, Kalita JC. Hepatoprotective activity of
Plumeria alba extract against paracetamol induced-hepatotoxicity in rats. Int J Pharm Sci 2010;4:618-20.

18. Kumari S, Mazumdera A, Bhattacharya S. In-vitro antifungal activity of the essential oil of flowers of Plumeria alba Linn. (Apocynaceae). Int J PharmTech Res 2012;4:208-12.

19. Gilman FE, Watson DG. Plumeria alba White Frangipani; 1994.

20. Prajapati ND, Purohit SS, Sharma AK. Handbook of Medicinal Plants. Jodhpur: Agrobios, India; 2004. p. 336-8.

21. Raju RA. A Textbook of Wild Plants of Indian Subcontinent andTheir Economic Use. New Delhi: CBS publishers; 2000. p. 145 